\title{
Effect of feeding frequency on the performance of Compact Vertical Flow Constructed Wetland treating faecal sludge leachate under high hydraulic load
}

\author{
Ebenezer SOH KENGNE ${ }^{1,2^{*}}$, Wilfried Arsenne LETAH NZOUEBOUET ${ }^{2}$, \\ Guy Valérie DJUMYOM ${ }^{2}$ and Ives Magloire KENGNE NOUMSI ${ }^{2}$
}

\author{
${ }^{I}$ Department of Biology, Higher Teachers Training College, The University of Bamenda, P.O. Box 39 \\ Bamenda, Cameroon. \\ ${ }^{2}$ Department of Plant Biology, Faculty of Science, The University of Yaoundé I, P.O. Box 812 \\ Yaoundé, Cameroon. \\ *Corresponding author; E-mail: sohkengnee@yahoo.fr; Tel: +237 677157422
}

\section{ACKNOWLEDGEMENTS}

This study was supported by (i) the Swiss National Centre of Competence in Research (NCCR), North-South: Research Partnerships for Mitigating Syndromes of Global Change co-funded by the Swiss National Science Foundation (SNSF) and the Swiss Agency for Development and Cooperation (SDC), (ii) Eawag/Sandec through its EPP program and (iii) the International Foundation for Science (IFS, Sweden, grant No. W/4115-2).

\begin{abstract}
The poor management of faecal sludge remains a crucial health and environmental concern in subSaharan Africa. The use of Vertical Flow Constructed Wetland (VFCW) as low-cost solution for the treatment of this special waste is possible if the hydraulic load and feeding operation are appropriate. This work investigates at a pilot-scale on the effect of fractioning the application of faecal sludge leachate from planted drying beds at the hydraulic loading rate of $150 \mathrm{~mm} / \mathrm{d}$ into one, two and three batches per day once a week on the treatment efficiency of VFCW. Results showed no significant differences $(P>0.05)$ in performance between one, two and three batches per day for all the monitored parameters with the exception of faecal coliforms. Three batches at 5 hours' intervals permitted to reach the Cameroonian guidelines for faecal coliforms discharge of effluent compared to two and one application daily, but not the overall nitrogen requirements. An effective treatment of faecal sludge can be envisaged: raw faecal sludge applied in batches on planted drying beds at $200 \mathrm{~kg} \mathrm{TS} / \mathrm{m}^{2} / \mathrm{yr}$. followed by a subsequent treatment on VFCW planted with Echinochloa pyramidalis at a loading rate of $150 \mathrm{~mm} / \mathrm{d}$ applied in three batches with at least 5 hours resting time between two feedings.
\end{abstract}

(C) 2019 International Formulae Group. All rights reserved

Keywords: Faecal sludge, hydraulic loading rate, feeding frequency, Vertical Flow Constructed Wetlands, Echinochloa pyramidalis.

\section{INTRODUCTION}

Faecal sludge and wastewater management is still a major health and environmental concern in Sub-Saharan Africa. Their appropriate and adequate levels of treatment prior to end use or discharge in the environment are imperative to provide human and environmental health protection (Strande et al., 2014). Constructed wetlands have been widely used for this purpose in Europe for the last three decades with a preference given to hybrid systems (first generation) which 
operate with parallel Vertical Flow (VF) beds dosed in rotation, followed by a number of Horizontal Flow (HF) beds in series for the treatment of wastewater (Kadlec and Wallace, 2009; Molle et al., 2006; Vymazal, 2007). The use of single VF beds (second generation) or Compact Vertical Flow beds (CVFCW) is more recent and data on its performance worldwide still in collection (Cooper, 2005).

The performances of VFCWs depend on many factors among which the hydraulic load rate and/or organic loading rates. The recommended values of 50 to $60 \mathrm{~mm} / \mathrm{d}$ (corresponding to 0.01 to $0.04 \mathrm{~kg} \mathrm{BOD}_{5} / \mathrm{m}^{2} / \mathrm{d}$ ) were settled in Europe for the operation of VFCW (Prochaska et al., 2007; Arias and Brix, 2005). Weedon (2003) reported the operation of Compact Vertical Flow beds at a range of 33-1027 mm/day without clogging of beds. This was earlier confirmed by Johansen et al. (2002) who noticed that loading beds at 200-1200 mm/d with wastewater did not flood them below $800 \mathrm{~mm} / \mathrm{d}$, but requires for a long term operation that the sand media on top the filter bed be of good size. For first generation beds, Cooper (2005) designed for a tertiary treatment plant, VFCW operating at a loading rate of $1500 \mathrm{~mm} / \mathrm{d}$ without clogging. Molle et al. (2006) also mentioned this adaptability of VFCW to changing hydraulic loading rate and raised the difficulty of finding a consensus on the hydraulic limit which yet is a requirement for decision making on to which extend VFCW can be adapted and to which king of wastewater.

Also related to the hydraulic in VFCW is the feeding operation. As mentioned by Brix and Arias (2005), recommended loading frequency at a normal loading rate (50-60 $\mathrm{mm} / \mathrm{d}$ ) for a household (1-5 PE) is 8-12 pulses per day. However, Molle et al. (2006) recommended in case of high hydraulic load, a feeding frequency with less pulses and long resting period to allow renewal of oxygen as they can lead to a better efficiency of filter beds and long term functioning. Therefore, for the same hydraulic load, the choice between numerous small volumes of batches or less batches of greater volume is determinant in operating VFCW. Unfortunately, very few data are available on how feeding operations affect the hydraulic and performance of VFCW.
In tropical regions in general and SubSaharan Africa in particular, the use of VFCW for wastewater treatment is recent (Maina et al., 2011) and study cases very few to give sufficient data to enable sizing and operation of this low-cost technology. The differences in climatic conditions, wastewater pollution strength and plant species of this region have render more difficult the transfer of VFCW's sizing and performances knowledge gained in temperate regions, therefore demanding more investigations.

This paper investigates on the effect of feeding frequency on the performance of Compact Vertical Flow Constructed Wetlands operated in high hydraulic load for the polishing of leachate from faecal sludge dewatering beds.

\section{MATERIALS AND METHODS \\ Presentation of the Site of Study}

Experiments were carried out in yardscale CVFCW units set up at the University of Yaoundé I, Cameroon. The site, situated 760 $\mathrm{m}$ above sea level at $3^{\circ} 45 \mathrm{~N}$ and $11^{\circ} 32 \mathrm{E}$, has a typical equatorial Guinean climate characterized by two rainy seasons (September to mid-November and mid-March to June) and two dry seasons (mid-November to mid-March and July to August). The annual rainfall averaged $1600 \mathrm{~mm}$ and the average daily temperatures vary between 22 and 35 ${ }^{\circ} \mathrm{C}$.

\section{Experimental Setup}

The experimental setup (Figure 1) consists mainly of two sets of six $1 \times 1 \times 1 \mathrm{~m}$ (length, width, height) experimental vats. The first set represents six drying beds of $1 \mathrm{~m}^{2}$ area each, mounted in parallel for the dewatering of raw faecal sludge collected in the town Yaounde and are connected to barrels for the collection of the liquid fraction (leachate). The second set of experimental units represent each a $1 \mathrm{~m}^{2}$ CVFCW bed in parallel, treating the above obtained leachate. All the beds are vegetated with $E$. pyramidalis. Each bed consisted of three layers of materials with increasing granulometry from top to bottom (15 $\mathrm{cm}$ of $0.3-2 \mathrm{~mm}$ diameter sand, $20 \mathrm{~cm}$ of 5-15 mm diameter semi-coarse gravel and 30 $\mathrm{cm}$ of $15-25 \mathrm{~mm}$ diameter coarse gravel). The porosities of these layers are $0.40,0.48$ and 0.50 for sand, semi-coarse gravel and coarse 
gravel layers respectively with a respective uniformity coefficient of 3.55, 1.67 and 1.37 .

\section{System operation and characterization of leachate and effluents \\ Planting of E. pyramidalis}

Robust E. pyramidalis cuttings were planted in CVFCW beds in a number of 12 per bed. Each bed was amended once with dry faecal sludge and watered with free running wastewater from the student dormitory for two months to allow plant growth and acclimatisation.

\section{Feeding operations}

Faecal sludge drying beds were batch fed once a week at a constant rate of $200 \mathrm{~kg}$ $\mathrm{TS} / \mathrm{m}^{2} / \mathrm{yr}$. by gravimetry with raw faecal sludge from public toilets and septage collected from mechanical emptier trucks and the leachate collected in polyethylene barrels. This leachate was then transferred into a storage tank where it was thoroughly mixed before application using a hand stirrer. The six CVFCWs beds were batch fed once a week at $150 \mathrm{~mm} / \mathrm{d}$ (recommended hydraulic load in Europe is $50-60 \mathrm{~mm} / \mathrm{d}$ ) applied into three different frequencies: one (7:00 a. m.), two (7:00 a.m. and 17 p.m.) and three times (7:00 a.m., 12:00 and 17: 00 p.m.) daily with one replicate, using a water pump and a splash plate for dispersion of leachate at the surface and for sand layer protection against the water current during application. The feeding of CVFCW was done according to the unsaturated down-flow mode as described by (Crites et al., 2006). The resulting effluents were collected in polyethylene containers located at the exit of the wetlands' drainage pipe and their volume measured using a graduated bucket.

During the operation, leachate and effluents were sampled in 10 sampling events based on the provenance of leachate from the planted drying beds. Leachate of a given raw faecal sludge provenance was applied for 1-3 weeks based on the availability of leachate from faecal sludge drying beds. Leachate and effluent were sampled and analysed for each application (the day before for leachate and at the end of the application day for effluent). Each time a leachate from a faecal sludge provenance was applied for 2-3 weeks, their effluents were analysed every application day and the characteristics of the effluent obtained at every analysis were averaged to give a single value therefore considered as a single sampling event.

For sampling, a $2 \mathrm{~L}$ transparent polyethylene bucket was used to collect homogenized leachate or effluent. From that bucket, water was sampled for in-situ and lab analyses. For lab analyses, a $1 \mathrm{~L}$ polyethylene bottle was used to collect leachate and effluent samples for chemical analyses whereas a $1 \mathrm{~L}$ sterilized borosilicate bottle was used for microbiological ones. Parameters such as $\mathrm{pH}$ and temperature were measured in-situ using a Hach pH-meter model HQ11d whereas Electrical Conductivity (EC) was taken using a Hach Conductimeter model HQ14d. COD, $\mathrm{NH}_{3}-\mathrm{N}, \mathrm{NO}_{3}-\mathrm{N}$ and $\mathrm{PO}_{4}-\mathrm{P}$ were analysed in the laboratory according to the standard methods for the analysis of water and wastewater (APHA, 2005) using the spectrophotometer Hach DR $3900 . \mathrm{BOD}_{5}$ was measured using the Oxytop method and Faecal coliforms the membrane filtration method. Total Suspended Solids (TSS) was measured using the gravimetry method by filtrating leachate and effluent through a glass fibre membrane of $0.45 \mu \mathrm{m}$ porosity and estimating the dry mass at $105{ }^{\circ} \mathrm{C}$. Total Kjeldahl Nitrogen (TKN) was performed through wet acid digestion followed by distillation in a Bucchi K-350 distiller and the determination through back titration with $\mathrm{H}_{2} \mathrm{SO}_{4} 0.1 \mathrm{~N}$ according to Rodier et al. (2009).

\section{Assessment of plant responses to the operation}

To appreciate the effect of the different feeding frequencies on the growth of E. pyramidalis, plant density was assessed every two weeks during the operation by counting living individuals in every wetland bed.

\section{Assessment of the rhizospheric bacteria density}

From October to December 2013, three soil samples were collected every two weeks in every CVFCW bed by coring the substrate at $15 \mathrm{~cm}$ depth using a $60 \mathrm{cc}$ syringe open on one end. The sampling was done diagonally (at one corner of the bed, the middle and the opposed corner) and the samples mixed together to form a composite 
sample. Three sub-samples per composite were analysed. Then, to a soil agar extract medium (solid culture medium), different dilutions of prepared soil samples were spread on the culture medium in petri dishes and incubated for 24 to 48 hours at $24-28{ }^{\circ} \mathrm{C}$ in a Sartorius microbiological incubator and the colonies formed counted using a magnifying glass as described in the Germida method (Germida, 1993). The number of rhizospheric bacteria was expressed in Colony Forming Units (CFU)/g of substrate.

\section{Assessment of the infiltration flow rate}

During the application of the hydraulic loading range of $150 \mathrm{~mm} / \mathrm{d}$ into 1,2 and 3 times daily, the infiltration flow rate was measured using a Fischer Scientific time recorder and graduated buckets at the exit of the beds. From the beginning of percolation to the end, five retention times were retained for the collection of effluents (5 min, $15 \mathrm{~min}, 30$ $\mathrm{min}, 45 \mathrm{~min}, 60 \mathrm{~min}$ ). The following formula was used for the calculation of the infiltration flow rate (D): $D=d V / d t$, with $\mathrm{dV}$ being the volume of effluent collected (in litres) and $\mathrm{dt}$ being the infiltration time (in minutes).

\section{Removal efficiency calculation}

For investigations on CVFCW and WSP, the removal efficiency was determined for each parameter measured using the following formulae, respectively.

$\operatorname{Removal}(\%)=\frac{(C \mathrm{CNVi})-(\mathrm{CeXVN})}{C \mathrm{CiNVi}} \times 100$

Where $\mathrm{Ci}$ is the concentration of the parameter in the influent (leachate); $\mathrm{Ce}$, the concentration in the effluent; $\mathrm{Vi}=$ volume of applied leachate; $\mathrm{Ve}=$ volume of effluent at the outlet.

\section{Statistical analysis}

The analysis of variance (ANOVA) associated to the T-Student test and the Kruskall-Wallis test were used to compare the effect of different loading frequencies on the morphometric parameters of plants as well as the rhizospheric bacteria density. It was also used to compare the effect of loading frequency on CVFCWs. The least significant difference was observed at the 5\% significance level.

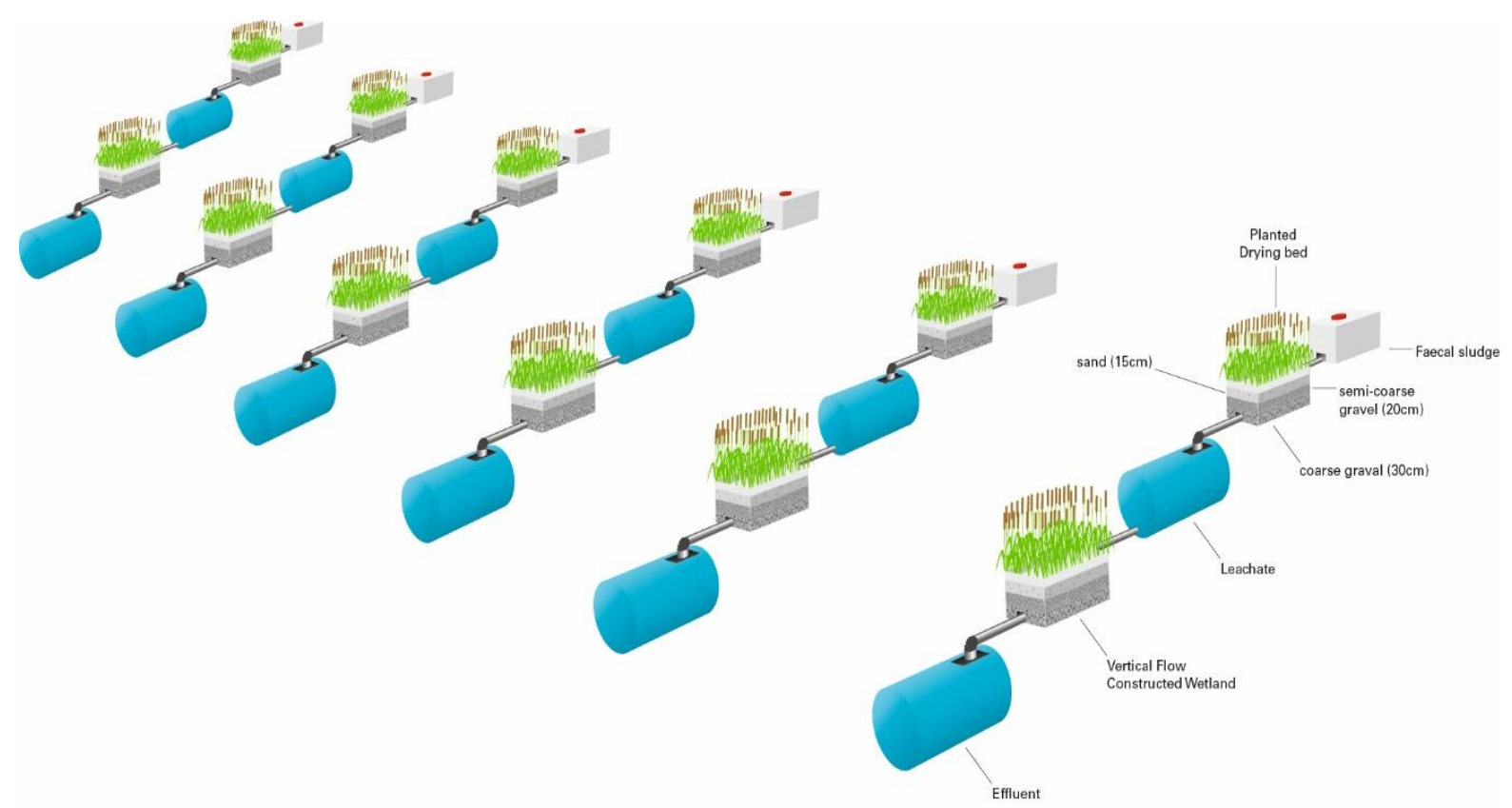

Figure 1: Schematic of the University of Yaoundé I pilot-scale faecal sludge treatment plant facility including how terminology is defined in this paper. 
RESULTS

\section{Characteristics of leachate from faecal sludge dewatering beds}

Leachates obtained from the dewatering of raw faecal sludge at the load of $200 \mathrm{~kg} \mathrm{TS} . \mathrm{m}^{2} . \mathrm{yr}^{-1}$ for the 10 sampling events were characterized (Table 1). Apart from $\mathrm{pH}$, EC, TDS and to a lesser extent phosphorus, all the parameters were above the guidelines for discharge, thus justifying their actual polishing treatment. There was also a great variation among the values of the different parameters measured during this investigation.

\section{Effluent volume}

The effluent collected after batch feeding the different CVFCW beds with 150 $\mathrm{mm} / \mathrm{d}$ in one, two and three applications daily are presented in Table 2 . It shows average volumes of $116.88 \mathrm{~L} \pm 7.56,109.08 \mathrm{~L} \pm 7.43$ and $118.73 \mathrm{~L} \pm 16.98$ out of the $150 \mathrm{~L}$ applied, respectively for one, two and three applications daily. It is about $3 / 4$ of the applied volume of leachate that was returned back after each application. One application daily produced the highest volume of effluent compared with two and three applications. However, there was no significant difference between the effluent returned back at one, two or three applications daily $(\mathrm{P}>0.5)$.

\section{Infiltration flow rate}

The infiltration flow rate assessed at one, two and three applications is presented in Figure 2. It shows that in overall, infiltration was maximal at $5 \mathrm{~min}$ after application and decreased progressively with time until 45 min where it tended to stabilise and became almost null after $1 \mathrm{~h}$. The infiltration peaks occurred 5 min after application of leachate on CVFWs' beds and were significantly different $(\mathrm{P}<0.5)$ between one, two and three applications daily with respective values of 12 $\mathrm{L} / \mathrm{min}, 6 \mathrm{~L} / \mathrm{min}$ and $2 \mathrm{~L} / \mathrm{min}$.

\section{Effluent characteristics}

The effluent characteristics throughout the period of study are presented in Figure 3.

\section{Physical parameters}

The electrical conductivity ranged between 217 - 1468, $140-1440.5,110$ $1469.5(\mu \mathrm{S} / \mathrm{cm})$ respectively for one, two and three applications daily, against $266-1547$ $\left(\mu \mathrm{S} . \mathrm{cm}^{-1}\right)$ in the leachate. However, the difference was not significant between the different feeding frequencies $(\mathrm{p}>0.05)$.

The $\mathrm{pH}$ was generally (7/10 times) within the acceptable range of $\mathrm{pH}$ for discharge of effluent. Values ranged between $5.61-7.15,5.51-7.08$ and $5.46-7.07$ for one, two and three applications daily respectively.

Total suspended solid was lower in effluent, with values ranging between $72-$ 99.50, 30-68.50 and $12.50-47.50\left(\mathrm{mg} . \mathrm{L}^{-1}\right)$ against 133-357 in leachate for a corresponding removal percentage of 86.50 , 90.42 and $92.91 \%$ respectively for applications in one, two and three batches daily. The difference between the different feeding frequencies was significant at $\mathrm{P}<$ 0.05 .

\section{Organic matter}

The concentration of $\mathrm{BOD}_{5}$ as well as COD were significantly reduced from the leachate to the effluent whatever the feeding operation. $\mathrm{BOD}_{5}$ values ranged from $4-42$, $3.5-32$ and $2-18$ for one, two and three applications daily respectively, against $20-$ $225\left(\mathrm{mg} . \mathrm{L}^{-1}\right)$ for leachate. COD values ranged from $19.50-396.50,19.50-274.50$ and 6 $237\left(\mathrm{mg}^{-1} \mathrm{~L}^{-1}\right)$ respectively for one, two and three applications against $65-806\left(\mathrm{mg} . \mathrm{L}^{-1}\right)$ in leachate. Corresponding Performances ranged from $68.18-87.16 \%, 81.46-93.06 \%$, $85.06-94.77 \%$ and $61.10-83.98 \%, 74.23-$ $88.65 \%$ and $71.33-94.54 \%$ respectively at one, two and three applications daily for $\mathrm{BOD}_{5}$ and COD. The best reduction of $\mathrm{BOD}_{5}$ concentration was observed at three applications per day with a resting period of 5 hours. COD presented a similar pattern, but with a less distinct reduction than for $\mathrm{BOD}_{5}$. The difference in the reduction of effluent $\mathrm{BOD}_{5}$ concentration was significant between one and three applications daily $(\mathrm{P}=0.02)$.

\section{Nutrient concentrations}

TKN concentration reduced after treatment. Values ranged from $14.45-118.60$ mg. $\mathrm{L}^{-1}$ in leachate to $9-18,7.23-18.6,8.83-$ 15.60 and $14.45-18.60\left(\mathrm{mg} . \mathrm{L}^{-1}\right)$ in effluent after treatment in wetlands at one, two and three 
applications daily respectively. This reduction of concentration corresponds to an average performance after fractioning the load into one, two and three applications of $64.94 \% \pm 15.61$, $70.38 \% \pm 11.8$ and $71.83 \% \pm 13.91$ respectively. $\mathrm{NH}_{4}-\mathrm{N}$ concentrations ranged from $5.06-82.50$ in leachate to $1.27-46.62,2.43-41.77,1.87-$ $36.62\left(\mathrm{mg}^{-1} \mathrm{~L}^{-1}\right)$ in effluent for a removal percentage of $62.21 \% \pm 17.01,71.18 \% \pm 10.93$, $77.83 \% \pm 10.74$ at one, two and three applications daily respectively. There was no significant difference for TKN and $\mathrm{NH}_{4}-\mathrm{N}$ between one, two and three applications $(\mathrm{p}>$ $0.05)$. The overall nitrogen reduction was not efficient as the guidelines for nitrogen in the effluent (30 mg. $\mathrm{L}^{-1}$ ) was not met.

The CVFCWs beds were effective in reducing phosphorous concentration in effluent. Values ranged in $\mathrm{mg}^{-\mathrm{L}^{-1}}$ from $32.1-$ 141 in leachate to $15.85,10.65-67.5$ and $8.82-51.75$ in effluent at respectively one, two and three applications daily. This corresponds to respective average performances of $69.50 \pm 12.52,72.70 \pm 7.49$ and 79.50 \pm 5.56. The difference in phosphorus removal was significant between loading frequencies $(\mathrm{P}<0.05)$.

\section{Bacterial concentration}

The reduction of faecal bio indicators was effective when applying leachate at 150 $\mathrm{mm} \cdot \mathrm{d}^{-1}$ in one, two and three applications daily. Faecal coliform values in $\log _{10}$ CFU/100 mL ranged from $3.49-4.66$ in leachate to $2.97-4.12,2.67-3.98,2.30-3.71$ in effluents, respectively at one, two and three applications daily. These reductions correspond to average removal percentages of $84.57 \pm 4.30,89.50 \pm 2.37$ and $92.57 \pm 1.09$ respectively for one, two and three applications daily. These performances were significantly different $(\mathrm{P}<0.05)$ for the three feeding frequencies. Applying the leachate at $150 \mathrm{~mm} \cdot \mathrm{d}^{-1}$ fractionated into three applications daily presented the best reduction of pathogen concentration with $75 \%$ of the values obtained in effluents complying with the Cameroonian guidelines for discharge and reuse of effluent $(2000 \mathrm{CFU} / 100 \mathrm{~mL}$ of faecal coliforms). However, the difference in the treatment was not significant whatever the loading frequency using the Kruskal-Wallis one-way analysis of variance $(p>0.05)$.

\section{Plant and rhizospheric bacteria density}

There was a continuous increase in plant density with time during the study, whatever the loading frequency (Figure 4A). The plant density did not significantly differ with the difference in the number of application $(\mathrm{P}>0.05)$.

The rhizospheric bacteria growth is shown in figure $4 \mathrm{~B}$. It showed that as from four weeks of operation (sampling events 5), rhizospheric bacteria density increased with time without any significant differences between the number of leachate applications ( $p>0.05$ ). Values ranged from $2.1-10 \mathrm{e}^{+6}$, $2.4-9.4 \mathrm{e}^{+6}$ and $5.3-11 \mathrm{e}^{+6}$ respectively for one, two and three applications daily.

Table 1: Physico-chemical and bacteriological characteristics of leachate collected from faecal sludge drying beds $(n=10)$ together with guidelines for discharge or reuse of effluent.

\begin{tabular}{llllll}
\hline Parameters & Mean \pm Sd & Min. & Max. & $\begin{array}{l}\text { Guidelines } \\
\text { MINEP* }\end{array}$ & WHO** \\
\hline $\mathrm{pH}$ & $6.56 \pm 0.77$ & 5.46 & 7.39 & $6-9$ & $6-8.5$ \\
\hline $\mathrm{TDS}(\mathrm{mg} / \mathrm{l})$ & $475.20 \pm 225.26$ & 130 & 772 & $/$ & $/$ \\
\hline $\mathrm{EC}(\mu \mathrm{S} / \mathrm{cm})$ & $977 \pm 502.26$ & 266 & 1757 & $/$ & $/$ \\
\hline $\mathrm{TSS}(\mathrm{mg} / \mathrm{L})$ & $220.30 \pm 74.44$ & 133 & 187 & 50 & 30 \\
\hline $\mathrm{COD}(\mathrm{mg} / \mathrm{l})$ & $512.70 \pm 238.44$ & 65 & 806 & 100 & $/$ \\
\hline $\mathrm{BOD}_{5}(\mathrm{mg} / \mathrm{l})$ & $112.80 \pm 71.96$ & 20 & 225 & 30 & $/$ \\
\hline
\end{tabular}




\begin{tabular}{|c|c|c|c|c|c|}
\hline TKN (mg/l) & $57.86 \pm 34.57$ & 23.30 & 118.6 & \multirow{3}{*}{30} & \multirow{3}{*}{30} \\
\hline $\mathrm{NH}_{4}-\mathrm{N}(\mathrm{mg} / \mathrm{l})$ & $31.97 \pm 21.50$ & 15.06 & 82.5 & & \\
\hline $\mathrm{NO}_{3}-\mathrm{N}(\mathrm{mg} / \mathrm{l})$ & $31.94 \pm 19.94$ & 00 & 34.45 & & \\
\hline $\mathrm{PO}_{4}-\mathrm{P}(\mathrm{mg} / \mathrm{l})$ & $8.32 \pm 3.79$ & 3.20 & 14.10 & 10 & 10 \\
\hline $\begin{array}{l}\text { Faecal Coliforms } \\
\text { (FCU/100 mL) }\end{array}$ & $26811 \pm 14505.99$ & 14505.99 & 59600.00 & 2000 & 1000 \\
\hline
\end{tabular}

Table 2: Mean and standard deviation of volumes (L) of effluent collected at the end of the day as function of feeding frequency.

\begin{tabular}{llll}
\hline Sampling events & One application (Once) & Two applications (Twice) & Three applications (Thrice) \\
\hline I & $115.25 \pm 10.75$ & $104.15 \pm 1.15$ & $96.50 \pm 9.50$ \\
\hline II & $126.75 \pm 0.75$ & $114.50 \pm 0.50$ & $143.15 \pm 3.35$ \\
\hline III & $124.50 \pm 8.50$ & $112.50 \pm 11.50$ & $141.25 \pm 1.75$ \\
\hline IV & $127.75 \pm 11.75$ & $112.50 \pm 11.50$ & $138 \pm 50$ \\
\hline V & $103.83 \pm 16.58$ & $116.25 \pm 2.75$ & $125.50 \pm 3.50$ \\
\hline VI & $117.75 \pm 1.75$ & $89.75 \pm 23.75$ & $93.43 \pm 6.33$ \\
\hline VII & $120 \pm 8.50$ & $112.65 \pm 11.85$ & $114 \pm 40$ \\
\hline VIII & $113.50 \pm 1.50$ & $113.5 \pm 8.50$ & $110.50 \pm 1.50$ \\
\hline X & $109 \pm 40$ & $105 \pm 20$ & $107 \pm 20$ \\
\hline
\end{tabular}

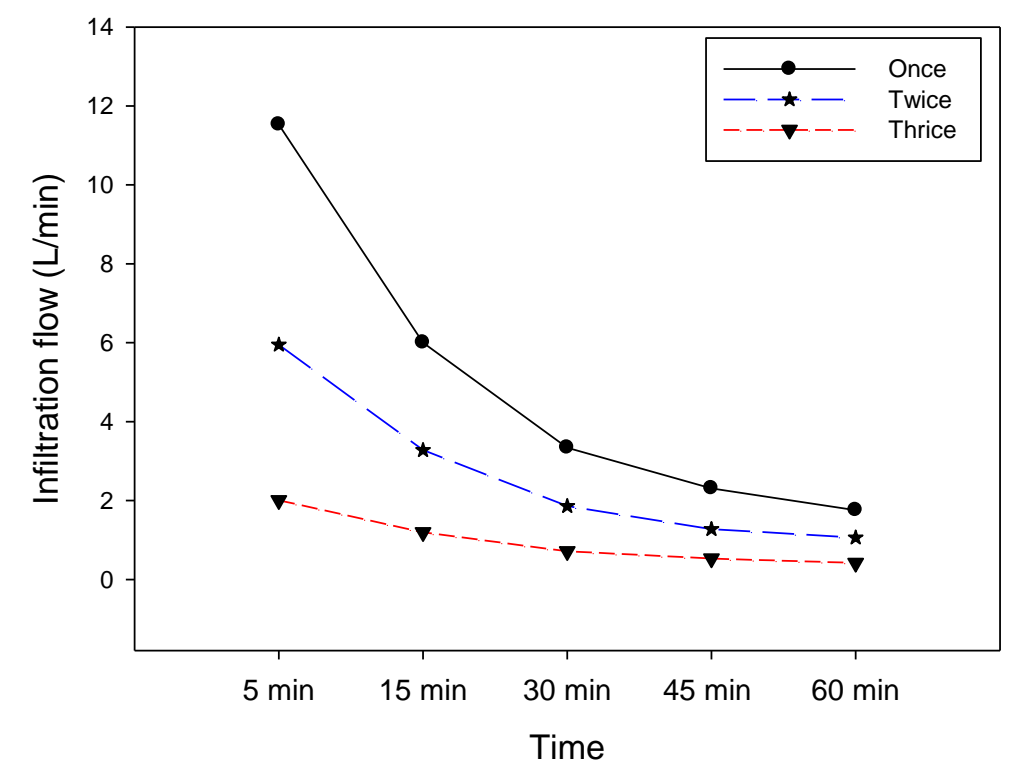

Figure 2: Infiltration flow rate as function of time and feeding frequencies. 

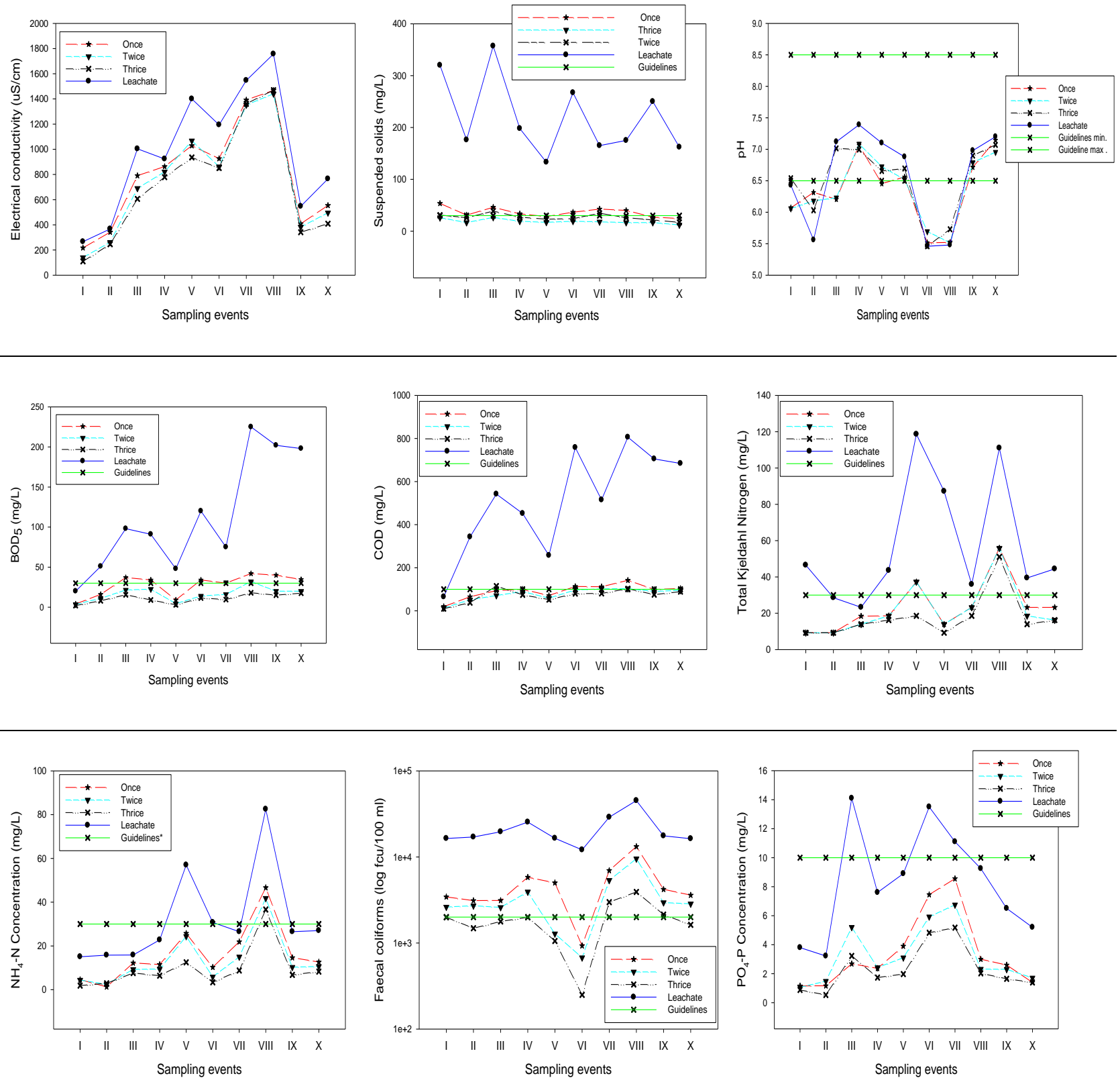

Figure 3: Characteristics of the effluents after treatment in CVFCW following one, two or three applications daily.

* Cameroon guidelines for wastewater effluent discharge edited by the Ministry of Environment and Nature Protection in Cameroon (MINEP, 2008). 


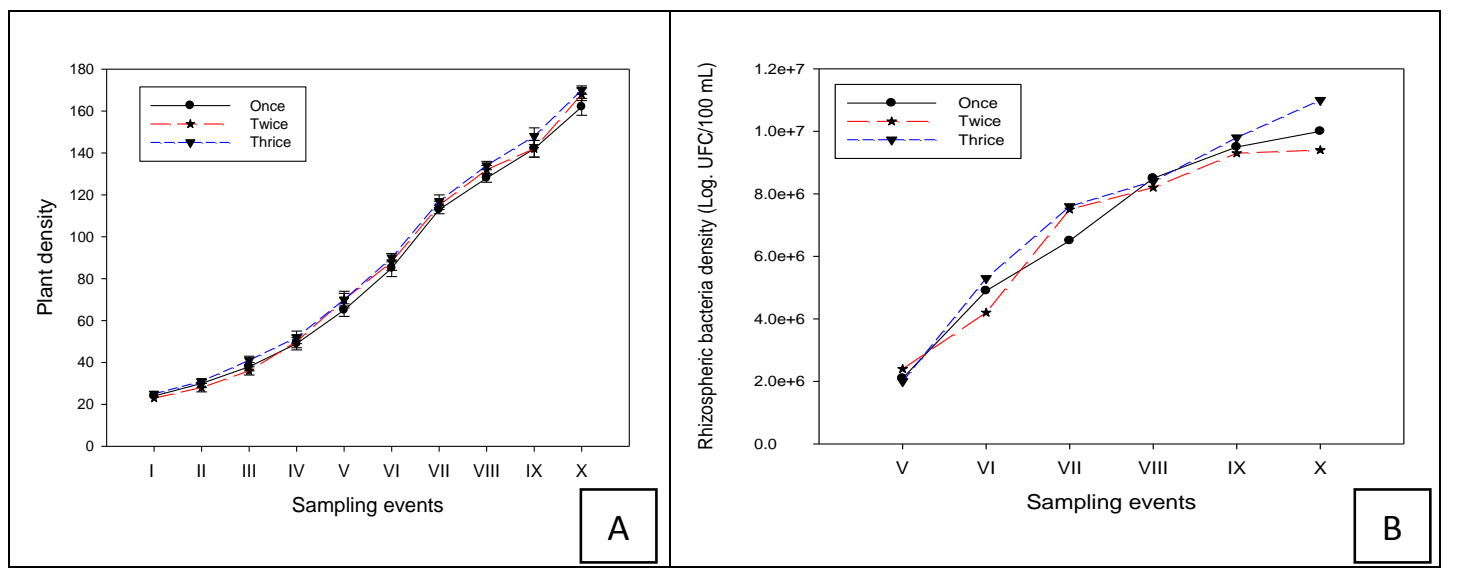

Figure 4: Evolution of plant and rhizospheric bacteria densities as function of the feeding frequency.

\section{DISCUSSION}

\section{Leachate characteristics}

Leachate characteristic showed that most of the parameters were above the WHO guidelines (WHO, 2006) as well as the Cameroonian standards (MINEP, 2008) of wastewater for discharge and/or reuse in nonrestricted agriculture. Such leachate strength is comparable to that obtained by Kengne et al. (2011) comparable to raw wastewater. The high variation of leachate quality observed between sampling events can be due to the variation in the origin and composition of raw faecal sludge from which they were obtained as explained by Soh et al. (2014).

\section{Effluent volume and infiltration rate}

The fact that $3 / 4$ of the leachate applied was returned back and about $99 \%$ of this volume within the first hour of application denotes a good drainage of the medium and a low evapotranspiration. This implies that CVFWs can be recommendable in case of reuse of effluent in agriculture as a good part of the water resource is conserved in the current situation of world's water wastage and shortage.

This infiltration rate was high at 5 min after application and decreased with time until it tended to stabilize about 45 min later.
This is probably because of the reduction of the pressure head gradient and the saturation of the media porosity by moisture immediately after application of leachate as mentioned (Molle et al., 2006). It also appears that applying high hydraulic load in a single batch leads to a high infiltration rate associated to a lower removal due to reduced contact time of leachate with microorganisms. Fractioning the hydraulic load into many applications reduced the infiltration rate, therefore increasing the retention time which in turns ensured a better removal efficiency has also demonstrated Molle et al. (2006) and (Stefanakis and Tsihrintzis (2012) in the study of VFCW performance treating wastewater under overloading. Nevertheless, Molle et al. (2006) emphasized on the fact that the resting time between two applications must be long enough to allow the VFCW beds to drain. This was the case in this study as the flow was unsaturated and the CVFCW beds never flooded.

\section{Physical parameters}

Physical parameters such as $\mathrm{pH}$, electrical conductivity did not significantly reduce from the leachate to the effluent nor were they significantly different between feeding frequencies. This can be due to the 
fact that none of the biochemical and physical process occurring in the system do affect them substantially in the sense of Kadlec and Wallace (2009). However, they influence other parameters. On the contrary, suspended solids were significantly different between the different feeding frequencies $(\mathrm{P}<0.05)$. Total suspended solids were reduced to the guidelines for discharge or reuse of effluent (MINEP, 2008). Their good removal in the system confirm the notorious role of VFCW in reducing TSS by filtration as reported by Vymazal (2007), the filtration efficiency been itself dependent on the infiltration rate.

\section{Organic matter}

Fractioning the hydraulic load of 150 $\mathrm{mm} / \mathrm{d}$ into one, two or three application daily did not significantly affect the performances $(P>0.05)$. Nevertheless, the highest removal percentages were obtained when applying this volume into three batches with a resting period of 5 hours. CVFCW beds ensured that the effluent concentrations always complied with the effluent requirements from wastewater treatment plants (MINEP, 2008). This good performance can be due as reported Molle et al. (2006) and Kadlec and Wallace (2009) to the presence of oxygen favoured by batch feeding which allows the introduction of air (oxygen) into the substrate media during resting periods. This available oxygen is then used as mentioned Molle (2003) by rhizospheric microorganisms to mineralize greater amounts of organic matter into mineral elements which are up-taken by plant for their growth. This explanation could justify the fact there was no significant difference in performances between the three different feeding frequencies as there was no significant difference in plant and rhizospheric bacteria density at the feeding frequencies. In addition to the biological uptake by microorganisms, retention of organic matter in suspended particles on the filter matrix was shown by Kadlec and Wallace (2009) to contribute significantly in removing organic pollutants. Therefore, a smooth infiltration associated to a prolong retention time favours these removal processes as observed by Molle et al. (2006) and Maine et al. (2011) and justify why the frequency of three applications daily rather than one or two applications presented the best efficiency. Nevertheless, although $150 \mathrm{~mm} / \mathrm{d}$ represents a high loading rate compared to the recommended loading rate in Europe (50 to $60 \mathrm{~mm} / \mathrm{d}$ according to Brix and Arias (2005), this loading rate was not enough to create any flood in the CVFCW beds and could not significantly affect the oxygen balance of the media so as to impact on the performances. This implies that the VFCW beds could support a more important volume of leachate without significant drop down of the oxygen availability of the media. In this sense, Johansen et al. (2002) and (Weedon, 2003) have reported a limit loading rate of $800 \mathrm{~mm} / \mathrm{d}$ and $1250 \mathrm{~mm} / \mathrm{d}$ respectively, at the condition the materials constituting the substrate are of a good drainage size. Hence, for this study, the hydraulic loading rate could be 6 times the applied one since the media material composition was shown by Kengne et al. (2011) to be of a good drainage property (uniformity coefficient of 3.55 for the sand filter layer). However, the effluent quality requirement must be observed, as Kadelec and Wallace (2009) demonstrated the treatment efficiency to reduce with the increase of the inflow pollutant concentrations.

\section{Nutrients removal}

Total nitrogen was effectively reduced, as shown by the reduction in TKN and $\mathrm{NH}_{4}-\mathrm{N}$. sThis reduction is due to plant uptake (mainly $\mathrm{NH}_{4}{ }^{+}$), adsorption, ammonia volatilization, and denitrification (Vymazal, 2007). The high nitrogen removal observed in this study was likely favored by the climate which, with an average daily temperature of $25^{\circ} \mathrm{C}$, increased the metabolic rates of plants and microorganisms, as well as temperaturedependent chemical nitrogen transformations. 
CVFCWs beds were effective at meeting Cameroonian phosphorous effluent requirements of $<10 \mathrm{mg} / \mathrm{L}$ (MINEP, 2008) at the loading rate of $150 \mathrm{~mm} / \mathrm{d}$. This retention of phosphorus in planted wetlands has also been observed by Vymazal, (2001) who obtained sequestrated phosphorus contents in the reed planted wetlands for the treatment of wastewater (about $75 \mathrm{~g} / \mathrm{m}^{2} / \mathrm{yr}$.). Phosphorus reduction in VFCWs is also due to sorption, plant uptake or accumulation of sludge resulting in formation of new sediment/substrate layers (Johansen et al., 2002). This therefore explains why no significant difference $(\mathrm{P}>0.05)$ was observed for performances between the different feeding frequencies as no significant difference $(\mathrm{P}>0.05)$ was observed in plant density as well as rhizospheric bacteria density. No accumulation of sludge was observed at the surface of the filter to account for any reduction in phosphorus concentration.

\section{Bacterial removal}

Faecal coliforms were effectively reduced at $150 \mathrm{~mm} / \mathrm{d}$, with performances averaging $84.57 \pm 4.30,89.50 \pm 2.37$ and $92.57 \pm 1.09$ respectively for one, two and three applications daily. These performances were significantly different at $\mathrm{P}<0.05$ for the three feeding frequencies. Although high removal rates were observed, the effluent values were still higher than those recommended by WHO (2006) for reuse in non-restricted agriculture $(<1000 \mathrm{CFU} / 100$ $\mathrm{mL}$ ). Nevertheless, when applying the hydraulic load 3 times daily, the effluent quality met the Cameroonian guidelines for discharge of effluent after treatment (2000 CFU/100 mL, as mentioned by MINEP (2008). Kadlec and Wallace (2009) reported similar performances in VFCW and horizontal flow wetlands treating wastewater with low hydraulic loading rate. Bacterial reduction has been correlated to the reduction of organic load depriving bacteria of substrate (Vymazal,
2007). Kadlec and Wallace (2009) also suggested that plants contribute in reducing the bacteria indicators. It can be deducted that the main difference in faecal coliforms removal is due to the infiltration rate and related retention time. In fact, contrary to one and two applications daily, fractioning the application into 3 times resulted into a reduced head gradient and inflow pollutant, giving enough time to ensure the elimination of microorganisms in presence of available oxygen, as experienced by Molle et al. (2006). This result also confirmed the statement of Kadlec and Wallace (2009) that performances are correlated to inflow pollutant concentrations and wetland's hydraulics.

\section{Plant and rhizospheric bacteria density}

There exists a strong correlation between macrophytes and rhizospheric microorganisms (Soh et al., 2014). As presented in figure $4 \mathrm{a}$ and $4 \mathrm{~b}$, the plant density and rhizospheric bacteria density respectively had the same tendency. They were not significantly different at $150 \mathrm{~mm} / \mathrm{d}$ (P> 0.05) between the different feeding frequencies. This implies that plant and microorganism growth in VFCW beds depend mainly on the organic loading rate rather than on the hydraulic as suggested Kadlec and Wallace (2009).

\section{Conclusion}

This work aim was to assess the effect of fractioning the application of leachate into one, two and three applications daily on the performances of CVFCWs. CVFCW was effective in treating leachate from planted drying beds at $150 \mathrm{~mm} / \mathrm{d}$ without clogging of beds. Fractioning this hydraulic load into one, two and three applications with a resting period of at least 5 hours did not significantly affect the performances of the CVFCW for most of the pollutants apart for faecal coliforms. This feeding frequency permitted the treatment to meet the Cameroonian guidelines for faecal coliforms 
discharge of effluent. Comparative studies foresee the same good performances with 5 times the tested hydraulic load $(5 \times 150$ $\mathrm{mm} / \mathrm{d}$ ) given the good size and drainage of the media.

\section{COMPETING INTERESTS}

The authors declare that they have no competing interests.

\section{AUTHORS' CONTRIBUTIONS}

ESK was the principal investigator. GVD worked on the phosphorus retention in CVFCWs. He also helps on the field during data collection. WALN looked at the effect of hydraulic load on the performance of CVFCWs polishing leachate from drying beds. He also contributed on the field in data collection. CW participated in operating the pilot treatment plant and monitoring the plant growth. IMKN supervised the work and secure the grants for this research.

\section{REFERENCES}

APHA. 2005. Standard Methods for the Examination of Water and Wastewater $\left(21^{\text {st }}\right.$ edn). American Public Health Association, American Water Works Association and Water and Environment Federation: Washington DC.

Arias CA, Brix H. 2005. Initial experience from a compact vertical flow constructed wetland treating single household wastewater in Natural and Constructed Wetlands: Nutrients, Metals and Management: 52-64.

Brix H, Arias CA. 2005. The use of vertical flow constructed wetlands for on-site treatment of domestic wastewater: New Danish guidelines. Ecological Engineering, 25: 491-500. DOI: 10.1016/j.watres.2005.11.026

Cooper P. 2005. The performance of vertical flow constructed wetland systems with special reference to the significance of oxygen transfer and hydraulic loading rates. Water Science and Technology, 51(9): 81-90.

Crites RW, Middlebrooks EJ, Reed SC. 2006. Natural Wastewater Treatment Systems. CRC- Taylor \& Francis Group: London.

Germida JJ. 1993. Cultural methods for soils microorganisms. In Soil Sampling and Methods of Analysis (2 edn), Carter MR (ed). EdLewis Publishers: Florida; 263275.

Johansen NH, Brix H, Arias C. 2002. Design and characterization of a compact constructed wetland removing BOD, nitrogen and phosphorus for single household sewage. Proceeding of the $8^{\text {th }}$ International Conference on Wetland Treatment for Water Pollution Control: Arusha, Tanzania.

Kadlec RH, Wallace SD. 2009. Treatment Wetlands $\left(2^{\text {nd }}\right.$ edn). Taylor \& Francis Group: Boca Raton, Florida.

Kengne IM, Soh KE, Amougou A, Bemmo N, Dodane PH, Koné D. 2011. Verticalflow constructed wetlands as an emerging solution for faecal sludge dewatering in developing countries. Washdev 11(1): 13-19. DOI: http//doi.org/10.2166/washdev. 2011.001

Maina CW, Mutua BM, Oduor SO. 2011. Evaluating performance of vertical flow constructed wetland under various hydraulic loading rates in effluent polishing. Washdev, 1(2): 144-151. DOI : http//doi.org/10.2166/washdev.2011.025

MINEP (Ministère de l'Environnement et de la Protection de la Nature) 2008. Normes environnementales et procédure d'inspection des installations industrielles et commerciales au Cameroun (Environment Guidelines and Inspection Procedures for Commercial and Industrial Settlements). MINEP: Yaoundé.

Molle P, Lienard A, Grasmick A, Iwema A. 2006. Effect of reeds and feeding operations on hydraulic behaviour of 
vertical flow constructed wetlands under hydraulic overloads. Water Research, 40: 606-612. DOI: http//doi.org/10.1016/j.watres.2005.11.0 26

Prochaska CA, Zouboulis AI, Esridge KM. 2007. Performance of pilot-scale vertical flow constructed wetlands, as affected by season, substrate, hydraulic load and frequency of application of simulated urban sewage. Ecol. Eng., 31: 57-66. DOI:

http//doi.org/10.1016/j.desal.2008.01.02 8

Rodier J, Legube B, Merlet N. 2009. Analyse de l'Eau ( $9^{\mathrm{e}}$ edn). Dunod: Paris.

Soh KE, Kengne IM, Letah NW, Amougou A, Hung NV, Strande L. 2014. Performance of vertical flow constructed wetlands for faecal sludge drying bed leachate: effect of hydraulic loading. Ecol. Eng., 71: 384-393. DOI: http// doi.org/ 10.1016. j. ecol. eng. 2014. 07.041

Stefanakis AI, Tsihrintzis VA. 2012. Effects of loading, resting period, temperature, porous media, vegetation and aeration on performance of pilot-scale vertical flow constructed wetlands. Chemical
Engineering Journal, 181-182: 416-430. DOI:

http//doi.org/10.1016/j.cej.2011.11.108

Strande L, Ronteltap M, Brdjanovic D. 2014. Faecal Sludge Management. Systems Approach for Implementation and Operation. IWA Publishing: London.

Vymazal J. 2001. Types of constructed wetlands for wastewater treatment: Their potential for nutrient removal. In Transformation of Nutrients in Natural and Constructed Wetlands. Backuys: Leiden; 1-93.

Vymazal J. 2007. Removal of nutrients in various types of constructed wetlands. Science of the Total Environment, 380: 48-65.

DOI: http//doi.org/10.1016/j.scitotenv.2006.09 .014

Weedon CM. 2003. Compact vertical flow reed bed systems-first two years' performance. Water Science and Technology, 48(5): 15-23.

WHO. 2006. WHO guidelines for the safe use of wastewater, excreta and greywater. Excreta and greywater use in agriculture (Vol. 2). WHO: Geneva. 